\title{
The Effect of Auditor's Technical Abilities on the Quality of Financial Statement Information
}

\author{
Prastika Suwandi Tjeng $^{1} \&$ Rina Nopianti ${ }^{2}$ \\ ${ }^{1}$ Accounting Department, Multimedia Nusantara University Jakarta, Indonesia \\ ${ }^{2}$ Accounting Department, Bina Bangsa University Serang, Indonesia \\ Correspondence: Prastika Suwandi Tjeng, Accounting Department, Multimedia Nusantara University, Jl. Scientia \\ Boulevard, Gading, Kec. Serpong, Tangerang, Banten 15227 Jakarta, Indonesia. E-mail: \\ prastika.suwandi@lecturer.umn.ac.id
}

Received: March 22, 2021

Accepted: May 2, 2021

Online Published: May 28, 2021

doi:10.5539/ijef.v13n6p129

URL: https://doi.org/10.5539/ijef.v13n6p129

\begin{abstract}
The aim of this research is to provide empirical evidence and a discussion of the impact of the professional capacity of the auditor built into the aspects of information quality in the financial statements, experience, and communication. This is a quantitative study that employs the explanatory approach. This study's subjects are public accounting companies in Banten. The sample used in this analysis is the auditor who has worked for at least two years in the public accounting company in Banten. Primary data obtained from the questionnaires are the data form used in this analysis. Structural equation modeling is the computational analytical approach used in this research. The compilation of this research from the data collection that has been done reveals a considerable positive effect on the quality of financial statement information between the technical capacities of the auditor. This research shows that the greater the technical capacity of the auditors involved, the higher the quality of information in the financial report.
\end{abstract}

Keywords: audit, technological capabilities, details on financial statements

\section{Introduction}

The audit process is the review of evidence against information in order to assess the level of proficiency between the information and the newly determined, where this is done by people who have adequate and independent abilities in the field of auditing (Mkoba \& Marnewick 2016). Audit is an important process because it provides confidence that the financial information displayed in the financial report is presented fairly in all respects, where the information is useful for users, and will lead to the economy (Francis, 2011). Several phenomena of audit cases that have an impact on its users include the case that happened to PT Garuda Indonesia, where auditors from well-known public accounting firms were penalized because the information displayed on audited financial statements was misleading. Another audit case has also happened to PT Kimia Farma, where a well-known auditor was also given a sanction for a similar case. From these two cases, auditors have an important function in providing assurance to the wider public that the information presented in the financial statements has been fairly presented and that information becomes one of the resources for users of financial information in making economic considerations.

The technical ability of the auditor is one of the determining components that affect the quality of information displayed in the audited financial report (Brunelli, 2018). Where with adequate technical capabilities, it is assumed that the auditor concerned is more capable of finding material misstatements and has a better ability to guarantee the fairness of the information contained in the financial reports (Brunelli, 2018). This mapping is supported by several previous studies, which reported that technical ability has a positive impact on financial information content (Aghaei, 2011; Mackenzie et al., 2014; Brown et al., 2016; Habiburrochman \& Manifesti 2018). However, there are still auditors from well-known public accounting firms who have been penalized because the information they provided was considered misleading. The size of the public accounting firm itself is often a benchmark for the technical capabilities of the auditor concerned. Where the size of the larger accounting firm is analogous to better technical capabilities, because large and well-known public accounting firms are considered to have greater resources (Altinkaya \& Yucel, 2013).

This study aims to provide empirical proof of the effects of auditors 'technical capabilities on the quality of 
financial statement information, in order to obtain additional theoretical insights regarding the effect of auditors' technical capabilities on the information quality of financial statement.

\section{Theoretical Review}

Audit is a process of reviewing evidence of information with the aim of assessing the level of proficiency between information and predetermined guidelines, and is carried out by parties who have sufficient technical capabilities and have an impartial attitude (independent) in the audit sector (Christensen et al., 2015; Mkoba \& Marnewick, 2016; Boiral et al., 2019).

Audit can be a quality assurance service if the auditors who carry out the audit process are able to describe the inconsistencies and frauds that occurred during the audit series because the auditor concerned has sufficient technical skills. The technical capability factor is a factor related to the perception that with adequate technical capability the auditor can detect errors and technical ability also reflects the three dimensions that must be possessed by the auditor, namely reputation, capability and assurance. With adequate technical capabilities, the auditor concerned is perceived as an auditor with a reputation, has adequate capabilities and is able to provide assurance (guarantee) for the work that has been done. Auditors with these criteria are believed to be able to use technical information and audit methods more effectively so that they can carry out a series of audit activities with good quality (Butcher et al., 2012; Hussein \& Hanefah, 2013).

The level of technical knowledge is related to knowledge which has a significant impact on the resources. With adequate technical skills, auditors can ask important questions in order to collect appropriate audit evidence that is used as the basis for conducting assurance services on the information presented in the financial statements (Steinbart et al., 2012).

From the explanation above, it can be concluded that auditing can be a valuable process because auditing is a process that has the capacity to ensure independently the authenticity of the accounts that can improve the efficiency of resource allocation owned by the entity concerned.

Along with the increasing complexity of business transactions and accounting standards, increasing the added value of the series of audit processes carried out (DeFond \& Zhang, 2014). The audit process can be carried out properly if the auditor concerned has adequate technical capabilities, which in turn will have an impact on the quality of financial statement information presented (Brunelli, 2018). Where this is in accordance with several basic theories regarding auditing, namely Policeman Theory, Credibility Theory, Information Theory and The Assurance Theory.

\subsection{Theory of Policeman}

This theory was a popular theory in the field of auditing in the 1940s. This theory explains how auditors act like a policeman who focuses on mathematical accuracy and prevents potential misstatements and detects fraud (Steinbart et al., 2012; Nwanyanwu, 2017; Brunelli, 2018).

Policeman theory is a theory that explains that auditing rests on the principle of arithmetic accuracy where the auditor is obliged to detect and prevent fraud (Dauda, 2019). However, over time, the focus of auditing has shifted from the function of verifying the truth and fairness of financial statements to being required to provide adequate assurance. In its development, Policeman Theory was unable to explain the role and purpose of auditing. The weakness of the Policeman Theory was later refined in Credibility Theory (Eid, 2014; Ajao \& Olamide, 2016).

\subsection{Theory of Credibility}

This theory explains that the fundamental benefit of the audit is to strengthen the reliability of financial statements. Audited financial reports are used by company managers to increase the trust of other parties as users of financial information and reduce information metrics. Where the information displayed on the financial statements has a function to confirm the financial condition of the company concerned (Hope \& Thomas, 2011; Rezaee et al., 2015).

Credibility Theory explains that the ability of information to influence its users will depend on the credibility of the information. Information sources with high credibility will be more influential than information with low credibility. The credibility of an information comes from the technical ability of the compilers of the information and the trust felt by users of financial information because of the technical capabilities of the compilers of financial information. Technical ability is described as a source of strength to be able to organize information into an accurate statement. Therefore, information compiled by those with adequate technical skills is analogous to having higher credibility than information compiled by people who do not have adequate technical skills. If 
this Credibility Theory is applied to an audit setting, it can be said that the more objective and competent financial information is presented, the users of the information will rely more on that information. Users of financial information expect to get information from auditors who have more adequate and more objective technical skills as a source of credibility of financial information (Steinbart et al., 2012; Habiburrochman \& Manifesti, 2018).

Based on Credibility Theory, auditing the financial statements is mostly concerned with adding credibility. Audited financial reports can increase the confidence of users of financial statements in all financial information displayed in the financial statements and increase confidence in the services provided by company management. This Credibility Theory emphasizes the explanatory ability of information in financial statements to provide explanations that users of financial information can understand in order to make economic decisions (Eid, 2014; Akther \& Xu, 2020).

\subsection{Theory of Information}

Decision making is an intrinsic part of current practice in the realm of accounting. Decision making is the basis of the demand for services provided by accountants, and it involves a difficult task. First, the demand for accountants' services, namely information, is something that is caused by those who believe that accounting information will help them in making decisions. Investors, lenders, employees, government and company management are the parties affected by the information presented by accountants. Second, accountants themselves are needed because of the need to make a number of complex decisions. For example, the accountant must determine the contents of the report to be presented to decision makers, estimate the amount of tax that will be presented and provide accounting consulting, relating to how different regulations will be interpreted by other parties, determine how it should be Combines the results of various information obtained from a series of audit processes to produce adequate audit report exposure, estimates the demand for audit services in order to plan the needs of each person carrying out a series of audit processes. The quality of these decisions will determine the success of accountants in the audit marketplace. To make better decisions, there are three things that can be done. First, change the information to be presented. Second, educating decision makers to change the way they process information. Third, replace decision makers with decision-making models.

Accountants will tend to take the first approach, namely changing information. However, the impact of this choice is not affected by decisions regarding other options. The impact of changing information will be influenced by how the information is used. Moreover, the characteristics of information will have an impact on the way that information is processed. In simple terms it can be stated that the structuring of information and the methods used to process information have an interactive impact on decision quality (Libby, 2017).

Financial reports are the main instrument for supervisory purposes. An alternative or complementary instrument to the supervisory principle is the information principle, which focuses on the necessity that information must enable users to make economic decisions. Investors request that financial reports be audited in relation to their interest in making investment decisions and assessing the expected returns and risks they may face. Investors consider the audit as an activity to improve the quality of financial information, where an explanation of this is further explained in The Assurance Theory. In addition, auditing is also assessed as an activity to improve the quality of data used in the internal decision-making process. More accurate data will improve internal decision making (Eid, 2014).

\subsection{Theory of Assurance}

Assurance is a matter related to estimation related to uncertainty. The level of the estimate will have an impact on what public accountants face in providing assurance of the estimated account balance with a greater range of uncertainty that is much greater than the materiality of the financial statements as a whole (Christensen et al., 2015). The assurance of a sustainable company report has long been a matter of debate. Company managers and assurance service providers are often accused of what must be done in order to fulfill public obligations. The basic essence of Assurance is that the information presented by the company is considered more reliable and credible if the information has been checked by an independent third party. The purpose of the assurance process provided by third parties is to provide a sense of security and comfort to those who will feel vulnerable to the personal interests of company managers (Smith et al., 2011).

A systematic assurance process can provide the level of assurance needed regarding the information presented in a report and the quality of that information because the responsibilities of the management system and stakeholders have become more specific to the information they need. The choice of the assurance service provider ultimately leads to the choice of the public accounting firm to use its services. The assurance itself is closely related to the technical capabilities of the auditor concerned, because the current role of auditors is not 
only limited to providing assurance of financial information but has also expanded from it due to increased demand from stakeholders. there will be a continuous presentation of information.

Assurance is a tool for supervision and control. Audit is a series of processes to provide assurance as a supervisory mechanism which is an integral part of a series of information asymmetry between company managers and users of financial information, where company managers will voluntarily provide assurance to users of financial information. This explanation is in accordance with the presentation of the seminal article Watts and Zimmerman (1983) which states that most company managers will voluntarily become the subject of examination regarding the company's financial statements, where this action will bring benefits to company managers. This is in accordance with the analogy that audits are a series of processes carried out in the context of a supervisory process to strengthen the credibility of corporate financial information (Aghaei, 2011; Wong \& Millington, 2014).

The assurance service provided by the public accounting firm illustrates a conclusion regarding the reliability of a written statement regarding the responsibilities of other parties. Where in the Assurance Service there are independent consulting resources which can enhance decision-makers' information quality. The responsibility of individuals to make business decisions will rest on the Assurance Service to help increase the reliability and relevance of the information that will be used as the basis for their decisions (Eid, 2014).

\subsection{Auditor's Technical Capability}

Technical ability is a concept that involves several fields (for example, knowledge, motivation, and pragmatic components). In the realm of auditing, technical ability can be defined as the ability of an auditor to understand the technical steps that must be taken during the implementation of a series of audit processes (Hussein \& Hanefah, 2013).

The ability needed to be a good auditor is not only understanding about accounts that must be debited or accounts that must be credited and also not only understanding a list of data requirements or a list of audit activity sequences. EF Schumacher in his statement explained that an auditor can read audit evidence repeatedly so that the auditor can understand it or if not, then the auditor can define its objectives and use audit techniques that can ensure that the auditor concerned has got what he is looking for in the audit process and get what he or she needs in order to properly run the series of audits. Schumacer's statement on closer inspection has pressure on auditors. By focusing on audit activities in the statement, the statement can be interpreted as follows: The auditor concerned may review the list of audit activities repeatedly in order to assure himself that the auditor concerned has carried out the audit procedures properly and orderly, or The auditor concerned can define the purpose of the audit performed and use his audit ability to ensure that the auditor concerned has met the requirements to achieve a good audit performance and has got what he needs.

Auditing is a complex process that involves a variety of different abilities and responsibilities. Also, under current conditions, auditors will continue to face increasing demand for audit services due to regulatory demands and client expectations. In the end, the auditor will face pressure to properly document the work done and at the other end, the auditor will face pressure to do the job properly, orderly, on time and not violating the predetermined budget. This pressure can lead to the "priority to complete list of activities" trap, which then traps the auditor concerned in the illusion to the auditor that if it is able to complete the work on time then the audit opinion given will surely be appropriate. Therefore, if the only audit technique that is mastered by the auditor in the context of conducting the audit is merely the fulfillment of the activities listed in the list of activities, the auditor concerned will undoubtedly fail to become a reliable auditor. Good technical ability is a fundamental point in achieving a successful series of audits.

This is nothing new to anyone and should be seen as the basis of a set of characteristics that all auditors are expected to have. A good auditor will continuously build his technical skills along with his career, which is known as "commitment to lifelong learning". Throughout his career, the auditor concerned must have ethical basics and avoid a "leave it as is" attitude when conducting in-depth reviews of issues that have the potential to reveal errors or fraud. This fundamentally will depend on the technical area, where the auditor concerned must maintain his technical abilities throughout the career. If the auditor does not conform to the technical rules, the auditor concerned can easily lose something important in the implementation of the audit which leads to the issuance of an inappropriate audit opinion.

The audit profession is not only about tick marks and knots in a list of audit procedures, but auditing is something that concerns people. Auditors need to have exceptions to a person's abilities. Auditors need to have the ability to deal with all types of clients in all types of client business situations. In certain situations, client personnel have fear of auditors because they don't like it when people peek over their shoulder. Thus auditors 
must have the ability to put client personnel in a position to defuse their prejudices and be able to empathize from the client's perspective. For auditors, it is also relevant to display respect for clients. Moreover, the client is the party that pays for the audit process to be carried out. A skill that is often neglected by many people is the skill to listen. Listening may seem like a simple skill, but few perform it well. Many auditors listen to things only to hear the answers they want to hear rather than to listen to understand. Most lists of audit activities ask only close-ended questions that prevent the client from being able to elaborate on the situation. When the client explains more deeply about their answer, the auditor must hear the client's answer in full, when the auditor loses a small part of the answer, this can result in the auditor misunderstanding the message conveyed by the client as a whole. In addition, a person with good technical skills is an important person in the audit working group. Therefore, auditors with good technical abilities must learn to be able to work in groups in order to achieve the goals of the work team together (Lim et al., 2016).

Brunelli (2018) explains the information content found in the financial statements from the auditor's side is very likely to be influenced by two factors, namely, the technical ability of the auditor and the quality of service or the character of the auditor concerned which consists of empathy, responsiveness, assurance (Brunelli, 2018). The concept of technical ability was first popularized in the management book by Boyatzis (1982) as a step to improve individual performance. Where in the book, it is explained that technical ability is a concept that is more suitable for use in the context of performance than the concept of intelligence because technical ability is described as an individual characteristic that can lead to better performance. In general, technical capability is seen as the human ability to complete certain tasks in an entity as the ability of a particular entity to perform certain functions in order to ensure the operational continuity of the entity. In the realm of auditors, there are several classifications of technical capabilities that auditors must possess in order to achieve effective performance. This characteristic can be in the form of knowledge needed or the ability to complete a job (Ali et al., 2018).

The technical ability of auditors in carrying out their duties in the audit sector is described in the first general standard (SA section 210 in SPAP, 2011). The standard states that audits must be carried out by those who have the ability and adequate training as auditors. Furthermore, in the third general standard (SA section 230 in SPAP, 2011), it is explained that in making audited financial reports, an auditor must use his professional skills very carefully. Therefore, each auditor is required to have a professional attitude and technical expertise that are qualified in carrying out their duties as an auditor (IAPI 2013).

Technical skills emerge as understandable from a career requirement and personal qualifications point of view. Technical abilities can be obtained from two things, namely from knowledge and experience in the context of ICT (information communication technology), social skills, and the overall management of a person's work which is coordinated among workers in the entity concerned. Technical capability development is seen as an important part of overall capability. This can be observed from the point of view that technical ability is clearly something that needs to be developed in order to increase one's ability working life in accordance with working and workplace shifts. Changes in information and communication technologies in particular and their use are seen as something that requires learning and development, despite the view of most people that ICT (information communication technology) is just a tool for doing work, and not a tool for compiling the content of work. the. Technical skills can be developed, especially through on-the-job learning. Among them, learning is related to the work community and the work itself. The most common ways are: sharing knowledge within the work community, learning about cases in the workplace (for example learning about problem solving), participation in training, comprehension of technical literature and other reference sources, collaboration beyond voluntary service and use of experience and expertise in other life fields.

Experience is one of the most discussed indicators of technical knowledge. Because technical knowledge emphasizes more on work-based learning methods, experience is often identified as the main element that builds technical knowledge. In a survey conducted by Paloniemi regarding technical ability using private employees as respondents, sources of technical knowledge were divided from three main sources: education and training, experience, and personal characteristics. From the survey, most respondents answered that experience was their main source in gaining technical skills. People are of the opinion that the importance of job experience in the overall management of their work and in knowing the work community and business fields is regarded as irreplaceable. This type of technical expertise is assessed as the most essential and cannot be gained by training.

However, while experience is the principal source of professional skill, the survey answers also show clearly that job experience is not sufficient. An fascinating problem during the survey was the relationship between schooling and experiential technological skills. The debate involves discussing how teaching and schooling need to be interconnected so that advanced education can be used to help anyone achieve the most from formal 
education in actual working circumstances. Educational time and work experience are among the issues respondents contemplate from their professional development point of view. This is seen as a challenge, especially in the area of IT, where learning requirements are high and quick (McNamara, 2013).

Apart from knowledge and experience, communication is also a part of building technical skills. Effective communication will bring many benefits to an entity. When communication skills become better, it will increase the ability of an entity and make the entity ffficiently. The more details the stronger the connection between the parts in an entity, better personal relationships and therefore it can improve individual performance in carrying workout. Effective contact is the basis of good working conditions, which proves that productivity will increase along with the conditions of workers who feel more satisfied and happy with the work they do which is dominated by a pleasant personal atmosphere. In fact, misinformation can have an impact on work in the work group which will have an impact on poor internal communication. Changes that occur, whether positive or negative, must be communicated to all parts of the entity or at least communicated to the parts of the entity that are likely to be impacted. This awareness would allow impacted individuals to know how to respond and how to cope with the implications. This is important for a company's decision-making by providing a strong communication mechanism (Steinbart et al., 2012; Oliván, 2017).

Good communication skills will allow auditors to have relationships and assessments with other people such as, for example, other staff, managers, partners and liens. In the world of technology where we live today, this technology can have a negative impact on the auditors' staff to be able to communicate effectively, especially when email is a substitute for communicating face-to-face between auditors and clients handled.

Good auditors will understand the importance of face-to-face communication and will strive to make face-to-face communication the main way of communication. It is important in the auditor's job to communicate verbally as the primary means of communication. In some cases, email should be the last choice of communication compared to face to face in person. The client wants to communicate directly with the auditor, the more effective the communication by the auditor, the better the conversation between the client and the auditor will be. Effective communication will emerge when the client can clearly understand what the auditors mean and say. To achieve this is not something easy but if the auditors concerned can realize effective communication, the audit work carried out will go in harmony with the communication carried out (Lim et al., 2016).

\subsection{Information Quality of Financial Report}

The quality of the information presented in financial report is determined by the value of accounting reporting. Throughout the world, requests for financial information have a criterion that quality of the financial statement information is capable of providing a clear and uncovered explanation. It is important to provide high quality financial reporting that can influence the investment decisions of users of that information and to improve market efficiency. The higher the accuracy of financial results, the greater the financial reports will serve investors and other consumers. In addition, the accuracy of financial statements is a broad term not just for financial information but also for other non-financial information which is helpful when taking decisions. (Herath, 2017). Information in the financial statements can be said to have quality if it has the adequacy of three criteria, namely, First, details can be included in the financial statements appropriate delivery relating to the entity's operations in certain matters such as cash flows, in order to provide adequate explanation of information to stakeholders. investors. Second, the details in the financial report is able to provide fair facts on the company's results and financial status. Third, the information in financial reports is transparent information and is not designed to allow embezzlement or harm its users (Elbannan, 2011; Achim, 2014).

Based on the Indonesian Institute of Accountants (IAI), auditing by auditors can be called a process that can produce adequate quality financial statement information if it meets auditing guidelines and or standards. Auditing standards section 161 states that the public accounting firm should also meet the auditing standards set out by IAI in conducting audits. According to IAI, auditing standards are divided into three parts, namely, First, general standards consisting of an explanation of guidelines regarding who is considered capable of carrying out audit tasks (having the ability and following the upgrading process in the audit field, having an impartial and skeptical character). Second, the standard of field work which consists of questions regarding the engagement, planning, supervision, collection and testing of evidence, findings and documentation. Third, reporting standards consisting of questions about being measured by job indicators according to SPAP, working paper reviews and report reviews (IAPI, 2013).

\subsection{Hypothesis Development}

In the context of auditing, the technical ability of the auditor is one of the important things that can have an 
impact on the quality information in the financial statements (Brunelli, 2018). The technical ability of auditors consists of several elements including knowledge, experience and communication skills (McNamara, 2013; Oliván, 2017). Brunelli (2018) explains that the quality of the information contained in the financial statements from the auditor's point of view is very likely to be influenced by the technical ability of the auditors. This explanation by Brunelli (2018) is in line with the explanation of the credibility theory that the fundamental benefit of the audit is to strengthen the reliability of financial reports. Audited financial reports are used by company managers to increase the trust of other parties as users of financial information and reduce information asymmetry.

Based on Credibility Theory, adding integrity to financial reporting is the primary feature of the audit, where audited financial reports are to increase the confidence of users of financial statements in all financial information displayed in financial statements in order to make economic decisions (Eid \& Mahmoud, 2014). Credibility Theory explains that the ability of information to influence users' decisions will depend on the credibility of the information. Where information sources that have high credibility will be more influential than information with low credibility. The credibility of the information depends on the technical ability of the compilers of the information and the trust felt by users of financial information. Technical ability is described as a source of strength to be able to organize information into an accurate statement. Therefore, information compiled by those with adequate technical capabilities is analogous to having higher credibility than information compiled by people who do not have adequate technical capabilities.

If this Credibility Theory is applied to an audit setting, it can be said that the more objective and competent financial information is presented, the more users of information will rely on that information. Users of financial information expect to get information from auditors who have more adequate and more objective technical skills as a source of credibility of financial information.

Previous research has been conducted supports the logic explanation described by Brunelli (2018) and the logical explanation from Credibility Theory. The results of their research explain that the technical ability possessed by auditors is indeed an important factor that can impair the accuracy of detail on financial statements, where their research results show that the technical ability of auditors has a major positive impact on the accuracy of details on financial statements (Agusti et al., 2013; Ernstberger et al., 2015; Brown et al., 2016; Mutiara, 2018). However, on the other hand, there are several other studies which state that the effect of technical knowledge has no important impact on financial information efficiency (Nwanyanwu, 2017; Butar-Butar \& Lily, 2018).

This study intends to prove the logical explanation described in Credibility Theory which is supported by several previous studies that have been conducted which stated that the technical capabilities of auditors have a significant positive effect on the quality of financial information (Agusti et al., 2013; Ernstberger et al., 2015; Brown et al., 2016; Mutiara, 2018). Based on this explanation, the hypothesis in this study is: The auditor's technical ability has a substantial positive impact on financial reporting quality.

\section{Method}

This research uses a quantitative method approach. This study intends to produce a description of the relationship between several variables, which is described in the form of a formula. The formula defines the connection between the variable concerned and the controlling variable. This variable is a variable that cannot be directly measured. (Latent Variable) (Sarstedt et al., 2014).

Hypothesis testing in this study uses the Structural Equation Modeling (SEM) approach. This method is the second generation after the Regression method. The SEM method has several advantages including that it can be used for research with variables that cannot be measured directly (latent variables) with smaller errors than the regression method. Data collection in this study was carried out by survey with a questionnaire that was distributed in the form of question items that were used as a tool to collect data in order to get illustrations about the research variables.

Meanwhile, the data used in this study are primary data. Primary data is data that is described directly from the first source. The population used in this study consists of auditors who carry out work at the Public Accounting Firm in Banten. The sample in this study consists of auditors who have carried out work at a public accounting firm in Banten with a minimum duration of two years of work. This sample is the choice in this study because auditors with a minimum service period of two years are assumed to have qualified experience and expertise in the field of auditing and have fundamental functions during the audit process.

\subsection{Operational Definition}

The operational definition in this study is as follows: 
a. Auditor's Technical Capability

The technical ability of the auditor is a matter related to the knowledge and experience and adequate communication skills of the auditor concerned. Because with good knowledge, experience and communication skills, it is hoped that the auditor concerned can carry out the audit well and can produce an audit opinion that can provide an overview of the fairness of the information presented in the financial statements (McNamara, 2013). Therefore, the variable of auditor's technical ability in this study is measured using the dimensions of knowledge, experience and communication.

b. Quality of Financial Statement Information Based on the Indonesian Institute of Accountants (IAI), auditing is a process carried out in order to produce adequate quality financial report information. The quality of the financial report information can be said to be adequate if it meets the standards as described in the auditing standard guidelines. In accordance with auditing standards 161, the quality of financial statement information in this study is measured using the dimensions of general reporting standards, field work standards and reporting standards (Public, 2011).

The structural equation according to the Structural Equation Modeling method is as follows:

Measurement Model:

Structural Model:

$$
\eta_{1}=\gamma_{11} \xi_{1}+\zeta_{1}
$$

Where as:

$$
\begin{aligned}
& X_{1}=\text { Knowledge } \\
& X_{2}=\text { Experience } \\
& X_{3}=\text { Communication } \\
& Y_{1}=\text { Standar Umum } \\
& Y_{2}=\text { Field Work Standards } \\
& Y_{3}=\text { Financial Reporting Standards } \\
& \xi_{1}=\text { Auditor's Technical Capability } \\
& \zeta=\text { Delta (Standard of Errors) } \\
& y_{1}=\text { Information Quality of Financial Report }
\end{aligned}
$$

\section{Analysis and Discussion}

\subsection{Confirmatory Factor Analysis of Technical Knowledge}

Confirmatory factor analysis (CFA) analysis is a useful analysis to determine the convergent validity and reliability of the constructs. Convergent validity is a measure that can provide an explanation of whether each measured indicator can suitably measure the dimensions of the construct being tested (Sarstedt et al. 2014). The results of the confirmatory factor analysis found the loading factor value and the error variance of the CFA competency model which can be described in Table 1 below:

Table 1. CFA technical capability

\begin{tabular}{lccccc}
\hline & Measurement Model & Std Loading & Std Loading & Error Variance \\
\hline X1.1.1 & $\leftarrow$ & Experience & 0.701 & 0.491401 & 0.601 \\
X1.1.2 & $\leftarrow$ & Experience & 0.664 & 0.440896 & 0.59 \\
X1.1.3 & $\leftarrow$ & Experience & 0.674 & 0.454276 & 0.63 \\
X1.1.4 & $\leftarrow$ & Experience & 0.549 & 0.301401 & 0.679 \\
X1.2.1 & $\leftarrow$ & Knowledge & 0.702 & 0.492804 & 0.568 \\
X1.2.2 & $\leftarrow$ & Knowledge & 0.795 & 0.632025 & 0.438 \\
X1.2.3 & $\leftarrow$ & Knowledge & 0.701 & 0.491401 & 0.57 \\
X1.2.4 & $\leftarrow$ & Knowledge & 0.603 & 0.363609 & 0.73 \\
X1.3.1 & $\leftarrow$ & Communication & 0.789 & 0.622521 & 0.443 \\
X1.3.2 & $\leftarrow$ & Communication & 0.551 & 0.303601 & 0.722 \\
X1.3.3 & $\leftarrow$ & Communication & 0.689 & 0.474721 & 0.578 \\
& & & 7.418 & 5.068656 & 6.549 \\
\hline
\end{tabular}

Source: research data (2020). 
By referring to the CFA analysis on the Technical Knowledge variable which has been described in Table 1, it can be seen that all the indicators that make up each dimension of the competency variable have a loading standard that has a value exceeding 0.5 . Therefore it can be concluded that the indicators that make up the technical Knowledge variable have met the convergent validity. To determine the reliability of the competency variable construct, the construct reliability and variance extracted values will be calculated with the following formula:

$$
\text { construct reliability }=\frac{(\Sigma \text { stdloading })^{2}}{(\Sigma \text { stdloading })^{2}+\sum e_{i}}=(7.418)^{2} /\left(7.418^{2}+6.549\right)=0.894
$$

From the above calculations, the construct reliability value is 0.894 . This figure exceeds 0.6 so that it can be stated that the auditor's technical ability variable is in accordance with the construct reliability.

\subsection{Confirmatory Factor Analysis}

\subsubsection{Information Quality of Financial Report}

The variable quality of financial report information is prepared based on the second order model from three dimensions, namely General Works Standards, field work standards and financial reporting standards. The results of the confirmatory factor analysis found the loading factor value and the error variance of the CFA audit quality model which can be seen in Table 2 .

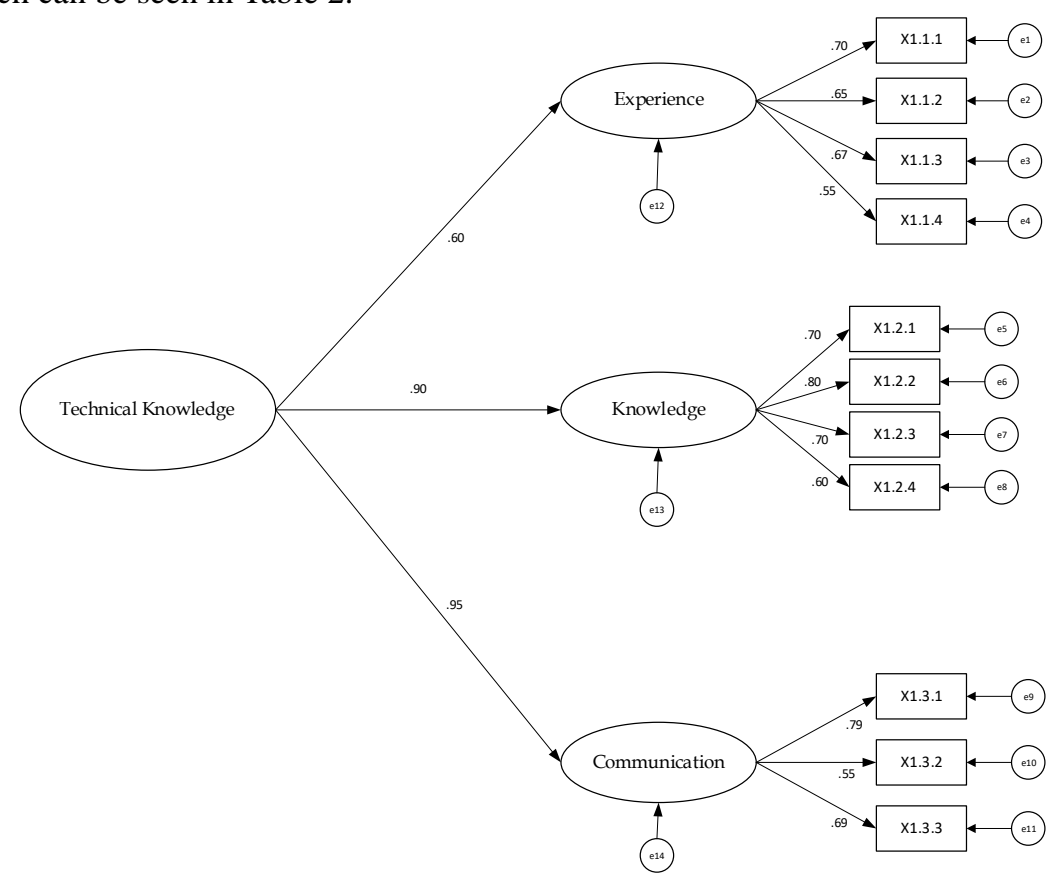

Figure 1. CPA second order technical capability

Table 2. CFA information quality of financial statements

\begin{tabular}{ccccc}
\hline & Measurement Model & Std Loading & Std Loading $^{2}$ & Error Variance \\
\hline Y1.1.1 & $\leftarrow$ General Works Standards & 0.601 & 0.361201 & 0.684 \\
Y1.1.2 & $\leftarrow$ General Works Standards & 0.85 & 0.7225 & 0.321 \\
X1.1.3 & $\leftarrow$ General Works Standards & 0.803 & 0.644809 & 0.395 \\
Y1.2.1 & $\leftarrow$ Financial Reporting Standards & 0.705 & 0.497025 & 0.634 \\
Y1.2.2 & $\leftarrow$ Financial Reporting Standards & 0.554 & 0.72 \\
Y1.2.3 & $\leftarrow$ Financial Reporting Standards & 0.55 & 0.3025 & 0.709 \\
Y1.2.4 & $\leftarrow$ Financial Reporting Standards & 0.649 & 0.421201 & 0.599 \\
Y1.2.5 & $\leftarrow$ Financial Reporting Standards & 0.699 & 0.488601 & 0.47 \\
Y1.2.6 & $\leftarrow$ Financial Reporting Standards & 0.603 & 0.363609 & 0.43 \\
Y1.2.7 & $\leftarrow$ Financial Reporting Standards & 0.749 & 0.561001 & 0.641 \\
Y1.2. & $\leftarrow$ Financial Reporting Standards & 0.699 & 0.488601 & 0.52 \\
Y1.3.1 & $\leftarrow$ Field Work Standards & 0.65 & 0.4225 & 0.671 \\
Y1.3.2 & $\leftarrow$ Field Work Standards & 0.751 & 0.564001 & 0.507 \\
Y1.3.3 & $\leftarrow$ Field Work Standards & 0.802 & 0.643204 & 0.56 \\
\hline Total & & 9.665 & 6.787669 & 7.861 \\
\hline
\end{tabular}

Source: research data (2020). 
Based on the CFA analysis table on the audit quality variable described in Table 2, it is known that all the indicators that make up each dimension in the variable quality of financial statement information exceed 0.5 . It can be concluded that the indicators that form the quality variable of financial statement information have met the convergent validity. To determine the reliability of the audit quality variable constructs, the construct reliability value will be calculated with the following formula:

$$
\text { construct reliability }=\frac{(\Sigma \text { stdloading })^{2}}{(\Sigma \text { stdloading })^{2}+\sum e_{i}}==(9.665) 2 /(9.6652+7.861)=0.922
$$

Referring to the above formula, the construct reliability value is 0.922 , where the value has exceeded 0.6 so that it can be stated that the variable quality of financial statement information has also met construct reliability. The next step in structural model analysis is to estimate the influence parameters between variables, which in turn proves the research hypothesis. Below is an overview of the parameter estimation results from the SEM analysis that has been carried out:

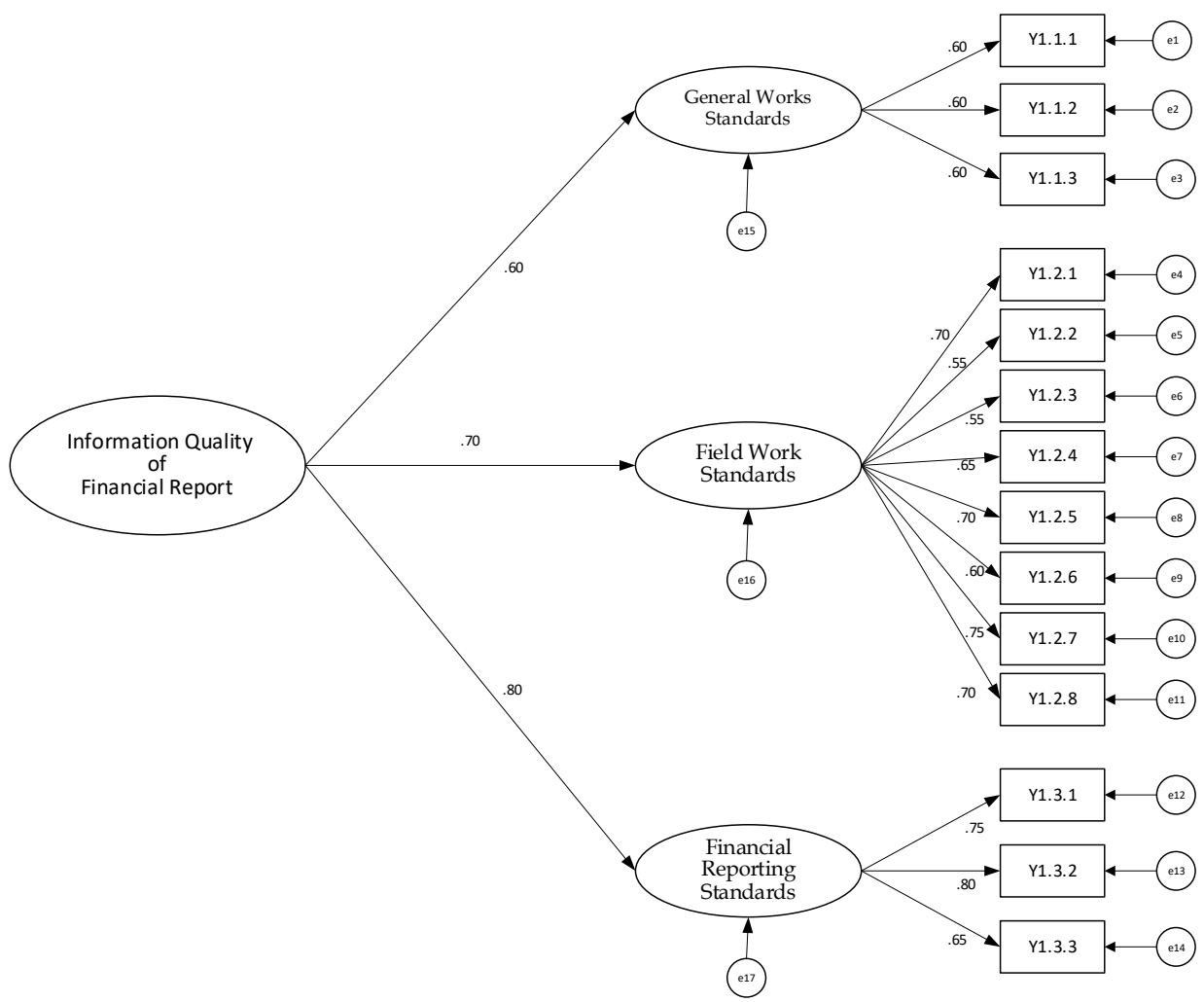

Figure 2. CFA second order quality of financial statement information

Tabel 3. Estimasi parameter

\begin{tabular}{ccccc}
\hline Relation & Coefficient Standard & C.R & P Value & Remarks \\
\hline Auditor's Technical Capability $\rightarrow$ Information Quality of Financial Report & 0.801 & 3.138 & 0.002 & Significant \\
\hline
\end{tabular}

\subsubsection{Standard Relationship}

Based on the results of the estimated influence parameters between these variables, it can be carried out to prove the research hypothesis regarding the effect of the auditor's technical ability on the quality of financial statement information is positive with a large influence of 0.801 . The resulting effect of competence on audit quality is significant because the $\mathrm{P}$ value is 0.002 , below 0.05 , which means that the hypothesis is accepted and Ho is rejected. Therefore the hypothesis which explains that the technical ability of auditors has a significant positive effect on the quality of financial statement information is proven to be true.

\subsection{Discussion}

The purpose of the positive effect of the auditor's technical ability on the quality of financial statement information is that when the auditor's technical ability increases, the quality of his financial statement 
information will also increase. This explanation is in accordance with what is disclosed by SPAP that the requirements for being able to be considered capable of carrying out duties in the audit sector, the auditor must fulfill two things, namely, first, have technical skills and have sufficient technical training as an auditor and secondly, the auditor must have professional skills and expertise in carrying out their duties as an auditor. The results of statistical tests show that there is a positive relationship between technical capabilities and the quality of financial report information, indicating that to achieve good quality financial report information, the auditor concerned must have adequate Knowledge, Experience and Communication skills. Because with good Knowledge and Experience, the auditor concerned has the ability to select appropriate and effective audit procedures to be used in the implementation of a series of audits to be carried out. In addition, with good communication, the auditor concerned will be greatly assisted in the process of gathering appropriate evidence, which will be used as the basis for issuing the appropriate audit opinion.

The positive relationship between technical capabilities and the quality of financial information, as presented in the results of this study, supports the four basic theories of auditing that have been described in the previous section. Where when the technical ability of the auditor in question increases, the quality of information in the financial statements will also increase. This is in accordance with the basic definition of the quality of the financial statement information itself, that the information in the financial statements is said to be of quality if the information can provide complete exposure and can become the basis for its users in making economic decisions. Information in financial statements can be said to have good quality if the information can describe the condition of the company entity that issues the financial statements in question. This definition is in accordance with the basic theory of auditing, namely the Policeman Theory, where the auditor is perceived to be in a similar position to a police officer, namely as a person who is able to find the mistakes of other parties (in this case the client) and explain these errors in the audit report. In addition, with good quality information, auditors can add sufficient credibility to the information displayed in the financial statements. Where this is in accordance with the audit theory Credibility Theory, which explains that the main function of the audit is to add credibility to financial statements. Where the audited financial statements should be able to increase the confidence of users of financial reports on all financial information displayed in the financial statements and increase confidence in the services provided by company management. This Credibility Theory emphasizes the explanatory ability of information in financial statements to provide explanations that users of financial information can understand in order to make economic decisions.

The positive relationship between the technical ability of auditors and the quality of information displayed in financial reports is also in accordance with the explanation of Information theory wherein this theory explains that decision making is an intrinsic part of current practice in the realm of accounting. Decision making is the basis of the demand for services provided by accountants, and it involves a difficult task. First, the demand for accountants' services, namely information, is something caused by those who believe that accounting information will help them in making decisions. Investors, lenders, employees, government, and company management are the parties affected by the information presented by accountants. Second, accountants themselves are needed because of the need to make several complex decisions.

With a positive relationship between technical capability and the quality of the information concerned, it can be said that when the technical ability of the auditor in question increases, the auditor can produce financial information that is believed to be able to assist in making investment decisions and other complex decisions related to the sustainability of the corporate entity. concerned.

\section{Conclusions and Suggestions}

\subsection{Conclusion}

By referring to the test results previously described, it can be stated that the auditor's technical ability has a significant positive effect on the quality of financial statement information. This result is in line with the results of previous research conducted by Agusti and Pertiwi (2013), Ilmiyanti and Suhardjo (2012), and Tjun et al. (2013) regarding the effect of technical expertise on the quality of financial statement information.

Where previous research explained that technical skills had a significant positive effect on the quality of financial statement information. The results of statistical processing are in accordance with the descriptions of the four audit theories that have been described in the theoretical review section, that the audit implementation is based on four main theories, namely Policeman Theory, Credibility Theory, Information Theory and Assurance Theory.

The four theories coherently explain that the audit is a complete package that is carried out starting from the basic principle that the main task of the auditor is to find irregularities and fraud during the audit process, to add 
credibility to financial information in published financial statements, to present the information informatively without any. the parts that are covered and provide a guarantee that the information presented is free from material misstatement in all respects. In the end, the positive relationship between the technical ability of auditors and the quality of information in the financial statements reflects the assurance function, as described in Policeman Theory, Credibility Theory, Information Theory, and Assurance theory. That the main function of the audit is to provide assurance to users of financial information. This assurance can be given to users of financial statements if the auditor concerned has sufficient technical capabilities to be able to produce information that is guaranteed to be fair in the context of making economic decisions.

Where the technical capabilities consist of Knowledge, Experience and Communication. Knowledge can lead the auditor concerned to the ability to select appropriate audit procedures in order to gather evidence, Experience or sufficient hours of flying in the audit can lead to a more sensitive instinct as an auditor in detecting material fraud and misstatement, while the ability Good communication will bring the auditor concerned to be able to communicate well to his clients so that the information needs needed can be met.

Remembering that auditing is not just a process to fulfill a list of procedures and understand accounting adjustment items. But the audit is a comprehensive process in which the auditor, as an audit implementer, is not only required to be someone who has technical understanding but is also able to communicate effectively and is willing to communicate directly with clients in order to direct clients to voluntarily describe the financial conditions that occur at companies, in order to collect adequate audit evidence as a basis for preparing an audit opinion.

\subsection{Suggestion}

This study has several limitations. First, this research was conducted using a questionnaire method, in which the questionnaire was submitted to the respondent and then filled in and returned by the respondent a few days after the questionnaire was completed. Where the questionnaire cannot be directly filled and returned. Second, this study only uses the auditor's technical ability as an independent variable that affects the quality of financial statement information. Based on the explanation of the limitations in this study, future research can improve the shortcomings of this research in several ways, including, first, collecting data by means of focus group discussions so that data can be obtained directly and can carry out direct supervision at the time of data collection., so that questions and answers can be done when filling out the questionnaire is taking place, so that researchers can also understand if there are items that are unclear, so that the required data becomes more valid. In addition, by carrying out a focus group discussion, the researcher can carry out direct supervision to find out whether the questionnaire has been filled in by the person concerned or not. Second, further research can use other variables that are considered to affect the quality of financial statement information, including the character possessed by the auditor. Third, further research may consider mixing methods so that in addition to using the questionnaire statement items, further researchers can get more in-depth answers through interviews with research subjects regarding other factors that are considered influencing the quality of information contained in the financial statements.

\section{References}

Achim, A. M., \& Chiş, A. O. (2014). Financial Accounting Quality And Its Defining Characteristics. SEA: Practical Application of Science, 2(3).

Agusti, R., \& Pertiwi, N. P. (2013). Pengaruh Kompetensi, Independensi dan Profesionalisme Terhadap Kualitas Audit (Studi Empiris Pada Kantor Akuntan Publik Se Sumatera). Jurnal Ekonomi, 21(03), 1-13.

Ajao, O. S., Olamide, J. O., \& Temitope, A. A. (2016). Evolution and Development of Auditing. Unique Journal of Business Management Research, 3(1), 032-040.

Akther, T., \& Xu, F. (2020). Existence of the Audit Expectation Gap and Its Impact on Stakeholders' Confidence: The Moderating Role of the Financial Reporting Council. International Journal of Financial Studies, 8(4), 1-25. https://doi.org/10.3390/ijfs8010004

Ali, N. A. M., Shahimi, S., \& Shafii, Z. (2018). Knowledge, Skills and Characteristics Requirements for Shari'ah Auditors. Asian Journal of Accounting and Governance, 9, 171-185. https://doi.org/10.17576/AJAG-2018-09-15

Amrin, A. (2016). Data Mining Dengan Regresi Linier Berganda Untuk Peramalan Tingkat Inflasi. Jurnal Techno Nusa Mandiri, 13(1), 74-79.

Arel, B. (2010). The influence of litigation risk and internal audit source on reliance decisions. Advances in 
Accounting, 26(2), 170-176. https://doi.org/10.1016/j.adiac.2010.05.002

Boiral, O., Heras-Saizarbitoria, L., \& Brotherton, M. C. (2019). Professionalizing the Assurance of Sustainability Reports: The Auditors' Perspective. Accounting, Auditing \& Accountability Journal, 33(2), 309-334. https://doi.org/10.1108/AAAJ-03-2019-3918

Brown, V. L., Gissel, J. L., \& Neely, D. G. (2016). Audit Quality Indicators: Perceptions of Junior-Level Auditors. Managerial Auditing Journal, 31(8/9), 949-980. https://doi.org/10.1108/MAJ-01-2016-1300

Brunelli, S. (2018). Audit Reporting for Going Concern Uncertainty: Global Trends and the Case Study of Italy. Springer, Switzerland. https://doi.org/10.1007/978-3-319-73046-2

Butar-Butar, S., \& Indarto, S. L. I. L. (2018). Does Auditor Industry Expertise Improve Audit Quality In Complex Business Environments? Jurnal Akuntansi dan Keuangan, 20(1), 1-12. https://doi.org/10.9744/jak.20.1.1-12

Butcher, K., Harrison, G., \& Ross, P. (2013). Perceptions of Audit Service Quality and Auditor Retention. International Journal of Auditing, 17(1), 54-74. https://doi.org/10.1111/j.1099-1123.2012.00457.x

Chadegani, A. A. (2011). Review of Studies on Audit Quality. International Conference on Humanities, Society, and Culture IPEDR, 20(2011), 312-317.

Christensen, B. E., Glover, S. M., \& Wood, D. A. (2012). Extreme Estimation Uncertainty in Fair Value Estimates: Implications for Audit Assurance. Auditing: A Journal of Practice \& Theory, 31(1), 127-146. https://doi.org/10.2308/ajpt-10191

Christensen, B. E., Glover, S. M., Omer, T. C., \& Shelley, M. K. (2016). Understanding Audit Quality: Insights from Audit Professionals and Investors. Contemporary Accounting Research, 33(4), 1648-1684. https://doi.org/10.1111/1911-3846.12212

Dauda, A., \& Olawale, B. V. (2019). The Place of Auditing in Organizational Performance of Public Sector: Evidence from some selected Local Government in Zamfara State, Nigeria. Journal of Accounting and Financial Management, 5(2), 10-17.

DeFond, M., \& Zhang, J. (2014). A Review of Archival Auditing Research. Journal of Accounting and Economics, 58(2-3), 275-326. https://doi.org/10.1016/j.jacceco.2014.09.002

Eid, A., \& Mahmoud, E. (2014). The Impact of Accounting Information Systems (AIS) on Performance Measures With Value Relevance of Auditors' communications. Internal Auditing \& Risk Management, IX(2), 13.

Elbannan, M. A. (2011). Accounting and Stock Market Effects of International Accounting Standards Adoption in an Emerging Economy. Review of Quantitative Finance and Accounting, 36(2), 207-245. https://doi.org/10.1007/s11156-010-0176-1

Ernstberger, J., Koch, C., \& Tan, H. T. (2015). What Dimensions of Lead Auditor Expertise Matter for Audit Quality and Audit Fees? Behavioral \& Experimental Accounting e-Journal, (2015). https://doi.org/10.2139/ssrn.2574639

Francis, J. R. (2011). A Framework for Understanding and Researching Audit Quality. AUDITING: A Journal of Practice \& Theory, 30(2), 125-152. https://doi.org/10.2308/ajpt-50006

Herath, S. K., \& Albarqi, N. (2017). Financial Reporting Quality: A Literature Review. International Journal of Business Management and Commerce, 2(2), 1-14.

Hope, O. K., Thomas, W., \& Vyas, D. (2011). Financial Credibility, Ownership, and Financing Constraints in Private Firms. Journal of International Business Studies, 42(7), 935-957. https://doi.org/10.1057/jibs.2011.23

Hussein, F. E., \& MohdHanefah, M. (2013). Overview of Surrogates to Measure Audit Quality. International Journal of Business and Management, 8(17), 84-91. https://doi.org/10.5539/ijbm.v8n17p84

Ilmiyati, F., \& Suhardjo, Y. (2012). Pengaruh Akuntabilitas dan Kompetensi Auditor terhadap Kualitas Audit. JURAKSI: Jurnal Akuntansi, 1(1), 43-56.

Jönsson, F., \& Ottosson, J. (2015). Mandatory Rotation of Audit Firms: A study on the investors' viewpoints in the EU and the US. Thesis, Jönköping International Business School. Jönköping, Swedia.

Libby, R. (2017). Accounting and Human Information Processing. The Routledge Companion to Behavioural Accounting Research, 42-54. https://doi.org/10.4324/9781315710129-3 
Lim, Y. M., Lee, T. H., Yap, C. S., \& Ling, C. C. (2016). Employability Skills, Personal Qualities, and Early Employment Problems of Entry-level Auditors: Perspectives from Employers, Lecturers, Auditors, and $\begin{array}{lllll}\text { Students. Journal of Education for Business, } & 91(4),\end{array}$ https://doi.org/10.1080/08832323.2016.1153998

McNamara, J. (2013). The Challenge of Assessing Professional Competence in Work Integrated Learning. $\begin{array}{lllll}\text { Assessment \& Evaluation in Higher Education, } & 38(2), & \text { 183-197. }\end{array}$ https://doi.org/10.1080/02602938.2011.618878

Mkoba, E., \& Marnewick, C. (2016). IT Project Success: a Conceptual Framework for IT Project Auditing Assurance. Proceedings of the Annual Conference of the South African Institute of Computer Scientists and Information Technologists, 1-8. https://doi.org/10.1145/2987491.2987495

Nwanyanwu, L. A. (2017). Audit Quality Practices and Financial Reporting in Nigeria. International Journal of Academic Research in Accounting, Finance and Management Sciences, 7(2), 145-155. https://doi.org/10.6007/IJARAFMS/v7-i2/2879

Oliván, J. B. (2017). Communication as an Element of Knowledge for the Company's Human Resources. Procedia-Social and Behavioral Sciences, 237, 1533-1536. https://doi.org/10.1016/j.sbspro.2017.02.241

Publik, I. A. I. K. A. (2011). Standar Profesional Akuntan Publik. Salemba Empat. Jakarta.

Rezaee, Z., Abernathy, J., Causholli, M., Michas, P. N., Roush, P. B., Rowe, S., \& Velury, U. K. (2016). Comments of the Auditing Standards Committee of the Auditing Section of the American Accounting Association on PCAOB Concept Release on Audit Quality Indicators, No. 2015005, July 1, 2015: Participating Committee Members. Current Issues in Auditing, 10(1), C11-C27. https://doi.org/10.2308/ciia-51316

Salifu, I., \& Mahama, M. (2015). The Evaluation of Evidence of the Audit Expectation Gap in Ghana. Research Journal of Finance and Accounting, 6(24), 20-30.

Sarstedt, M., Ringle, C. M., Smith, D., Reams, R., \& Hair Jr, J. F. (2014). Partial Least Squares Structural Equation Modeling (PLS-SEM): A Useful Tool for Family Business Researchers. Journal of Family Business Strategy, 5(1), 105-115. https://doi.org/10.1016/j.jfbs.2014.01.002

Smith, J., Haniffa, R., \& Fairbrass, J. (2011). A Conceptual Framework for Investigating 'capture' in Corporate Sustainability Reporting Assurance. Journal of Business Ethics, 99(3), 425-439. https://doi.org/10.1007/s10551-010-0661-4

Steinbart, P. J., Raschke, R. L.,. Gal, G., \& Dilla, W. N. (2012). The Relationship between Internal Audit and Information Security: An Exploratory Investigation. International Journal of Accounting Information Systems, 13(3), 228-243. https://doi.org/10.1016/j.accinf.2012.06.007

Suyono, E. (2012). Determinant Factors Affecting the Audit Quality: An Indonesian Perspective. Global Review of Accounting and Finance, 3(2), 42-57.

Tjun, L. T., Marpaung, E. I., \& Setiawan, S. (2013). Pengaruh Kompetensi dan Independensi Auditor terhadap Kualitas Audit. Jurnal Akuntansi Maranatha, 4(1), 33-56. https://doi.org/10.35141/jraj.v1i2.60

Wong, R., \& Millington, A. (2014). Corporate Social Disclosures: a User Perspective on Assurance. Accounting, Auditing \& Accountability Journal, 27(5), 863-887. https://doi.org/10.1108/AAAJ-06-2013-1389

\section{Copyrights}

Copyright for this article is retained by the author(s), with first publication rights granted to the journal.

This is an open-access article distributed under the terms and conditions of the Creative Commons Attribution license (http://creativecommons.org/licenses/by/4.0/). 